\title{
An approach to increasing the load-bearing capacity of drilled injection piles
}

\author{
Nikolay Sokolov*1,2[0000-0001-6729-7003] \\ ${ }^{1}$ Chuvash State University named after I.N. Ulyanov, 428015 Cheboksary, Russia \\ ${ }^{2} \mathrm{OOO}$ «NPF Forst», 428000 Cheboksary, Russia
}

\begin{abstract}
The problem of strengthening weak or overloaded bases is an important objective of underground space development. It is especially urgent if there are alternating weak layers in the base. The paper presents a practical geotechnical case of strengthening the overloaded base of a reinforced concrete foundation plate for a 25 -storey residential building under construction. Combined soil piles that consist of Jet (type 1) soil concrete piles reinforced along the longitudinal axis with drilled injection piles made by electric discharge technology (EDT piles) are used as buried structures. This method of arrangement of a combined buried reinforced concrete structure is conditioned by the need to increase the load-bearing capacity of a pile in soil by two or more times.
\end{abstract}

Keywords. Drilled injection EDT pile, Soil-cement pile, Jet grouting technology, Load-bearing capacity.

\section{Introduction}

Modern geotechnical construction shall comply increased requirements [1-4], which is justified in most cases. But it is often impossible to reach design values of the base load-bearing capacity using existing geotechnical technologies. Their combination makes it possible to build an underground structure with increased load-bearing capacity and thereby to solve most of the problems that arise both in the course of construction and during the facility operation.

The example of strengthening the base of a reinforced concrete slab foundation of a multistorey residential building is given below.

\section{Methods and materials}

The building under consideration began to deform at a rate of up to $2.0 \mathrm{~mm}$ per week during its construction ( 5 floors had already been built). We applied reinforcement based on the technology proposed in [5-12], which is a synthesis of 3 geotechnical technologies:

1. Jet-technology. It is soil-cement pile installation according to CR (Construction Rules) 291.1325800.2017 Reinforced soil-cement structures. Design rules Moscow. 2017.

*Corresponding author: ns_sokolov@mail.ru 
2. CFA-technology. It is drilled injection pile installation with the help of continuous flight augers (CFA) in the body of the soil-cement array along its symmetry axis, usually with a diameter of no more than $300 \mathrm{~mm}$.

3. Discharge-pulse technology used for drilled injection pile installation. The electrohydraulic effect that occurs when processing of fine-grained concrete contributes to its embedding into the soil-cement array. Thus, a more complete adhesion of these two structural elements happens.

This circumstance makes it possible to design a fundamentally new underground reinforced concrete structure - a soil-concrete pile.

\section{Results and discussion}

Fig. 1 shows the scheme of the combined soil-concrete pile arrangement. The buried reinforced concrete structure, i.e., a soil-concrete pile (SCP), shown in Fig. 1b, unlike other types, has a complex cross-section structure. An electro-hydraulically treated and reinforced SFA pile (position 3) serves as a load-bearing element. Its load-bearing capacity along the outer surface depends on the friction characteristics of the soil-cement component (position 1) (Fig. 2).

Table 1. Normative and calculated physical and mechanical properties of the soils.

\begin{tabular}{|c|c|c|c|c|c|c|c|c|c|c|c|}
\hline \multirow{2}{*}{$\begin{array}{l}\text { № } \\
\text { EGE }\end{array}$} & \multirow{2}{*}{$\begin{array}{l}\text { Name } \\
\text { of the soil }\end{array}$} & \multirow{2}{*}{$\sum_{1=i}^{\infty}$} & \multicolumn{3}{|c|}{$\begin{array}{c}\text { Normative } \\
\text { characteristics }\end{array}$} & \multicolumn{3}{|c|}{$\begin{array}{c}\text { Calculated values of } \\
\text { the characteristics at } \\
\alpha=0.85\end{array}$} & \multicolumn{3}{|c|}{$\begin{array}{c}\text { Calculated values of } \\
\text { the characteristics at } \\
\alpha=0.95\end{array}$} \\
\hline & & & $\left.200\right|_{\tilde{\omega}} ^{m}$ & $\sum_{0}^{\infty}$ & 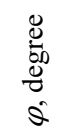 & $\left.200\right|^{\infty} \sum_{\omega}^{E}$ & $\sum_{0}^{\pi}$ & 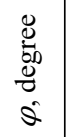 & $\left.\left.200\right|^{\infty}\right|_{\tilde{m}} ^{m}$ & $\sum_{i}^{\infty}$ & 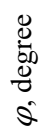 \\
\hline X(1) & $\begin{array}{l}\text { Bulk soil sand } \\
\text { with the } \\
\text { inclusion of } 10 \% \\
\text { of construction } \\
\text { debris }\end{array}$ & \multicolumn{10}{|c|}{ Design resistance $R_{0}=200 \mathrm{kPa}$} \\
\hline (2) & $\begin{array}{l}\text { Fine sand of } \\
\text { medium } \\
\text { density }\end{array}$ & 25 & $\frac{1.99}{1.79}$ & 1 & 32 & $\frac{1.97}{1.77}$ & 1 & 30 & $\frac{1.95}{1.75}$ & - & 29 \\
\hline$\therefore 20$ & $\begin{array}{l}\text { Fine, dense } \\
\text { sand }\end{array}$ & 38 & $\frac{2.10}{1.90}$ & 5 & 36 & $\frac{2.08}{1.88}$ & 5 & 34 & $\frac{2.06}{1.86}$ & 3 & 33 \\
\hline (20): & $\begin{array}{l}\text { Fine, loose } \\
\text { sand }\end{array}$ & 18 & $\frac{1.93}{1.73}$ & - & 28 & $\frac{1.91}{1.71}$ & - & 27 & $\frac{1.89}{1.69}$ & - & 26 \\
\hline (3) & $\begin{array}{lr}\text { Sand } & \text { of } \\
\text { medium } & \text { size, } \\
\text { medium } & \\
\text { density } & \\
\end{array}$ & 28 & $\frac{2.02}{1.82}$ & 1 & 33 & $\frac{2.00}{1.80}$ & 1 & 32 & $\frac{1.98}{1.78}$ & - & 31 \\
\hline (30) & $\begin{array}{l}\text { Medium- } \\
\text { sized, loose } \\
\text { sand }\end{array}$ & 18 & $\frac{1.95}{1.75}$ & - & 27 & $\frac{1.93}{1.73}$ & - & 26 & $\frac{1.91}{1.71}$ & - & 25 \\
\hline (5) & $\begin{array}{l}\text { Soft-plastic } \\
\text { loam }\end{array}$ & 18 & 2.00 & 12 & 23 & 1.98 & 12 & 22 & 1.96 & 8 & 21 \\
\hline E(5)] & $\begin{array}{l}\text { Semi-hard } \\
\text { clay }\end{array}$ & 15 & 1.72 & 75 & 15 & 1.71 & 75 & 14 & 1.71 & 50 & 13 \\
\hline
\end{tabular}



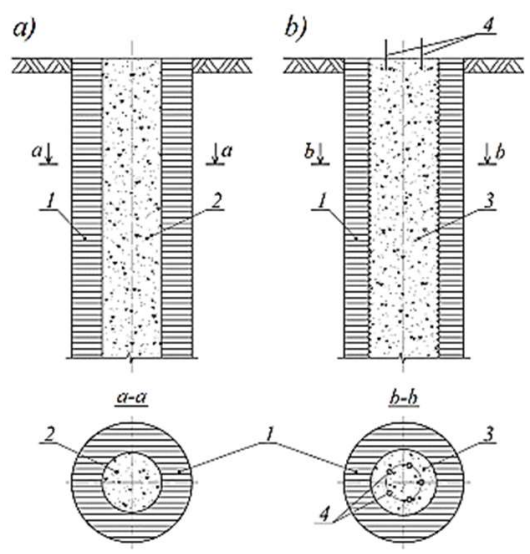

Fig. 1. Scheme of soil-concrete pile (SCP) arrangement.

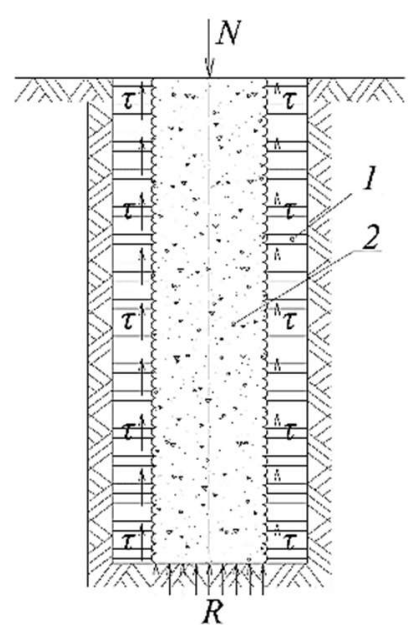

Fig. 2. Scheme for determining load-bearing capacity of CFA pile in soil-cement base: 1 - soil-cement array; 2 - CFA pile.

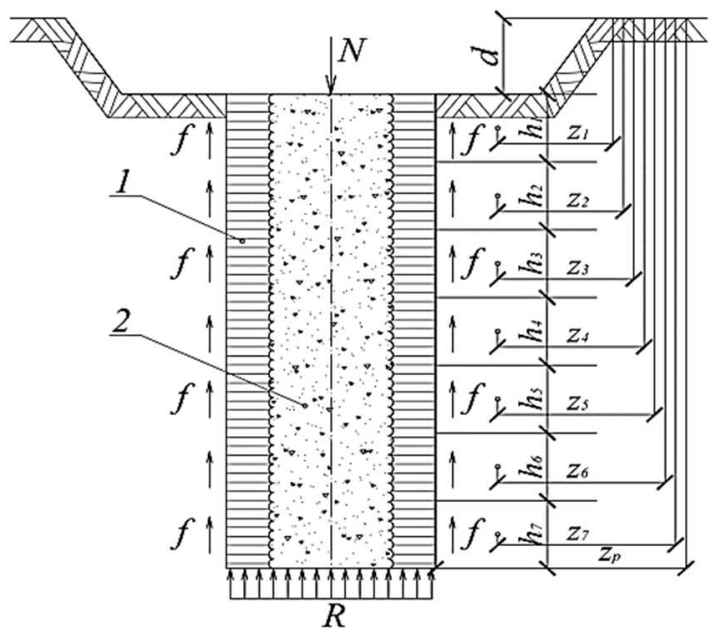

Fig. 3. Scheme for determining load-bearing capacity of CFA pile in soil together with soil-cement array (soil-concrete piles (SCP): 1 - soil-cement array; 2 - CFA pile. 
What is more, the CFA pile, together with the soil-cement array, works as a reinforced concrete pile of friction along the lateral surface with the surrounding soil (Fig. 3). The crosssection of the engineering-geological base reinforced by combined soil-concrete piles is represented by bulk soils, sands from fine to medium-grained, from wet to water-saturated states, as well as loams of soft-plastic consistency, solid and semi-solid clays. The description of engineering-geological elements (EGE) and EGE physical-mechanical characteristics are given in the Table below.

As a result of the engineering geotechnical calculations of the base, taking into account the real engineering and geological conditions of the construction site, the bearing capacity deficiency of the base of the slab foundation was revealed. At the same time, it is up to $50.0 \%$ of the design values. It should be noted that the height of the basement is $3.3 \mathrm{~m}$. Based on this, the choice of existing geotechnical technologies for strengthening the base under consideration is not very large.

If we consider the Get-technology as the base reinforcement design, then a soil-cement pile is capable of bearing up to $50.0 \mathrm{tf}(500.0 \mathrm{kN})$ in cross-sectional strength with a diameter of $\varnothing 600.0 \mathrm{~mm}$. At the same time, it should receive up to 120.0 ton-force $(1200.0 \mathrm{kN})$ to overcome the design load shortage. The use of a soil-concrete pile (SCP) solves this problem. Arranging a soil-concrete pile and reinforcing it with drilled injection piles of $\emptyset 250.0 \mathrm{~mm}$ made by the electro-discharge technology according to the algorithm (given in [13]), the problem of restoring the bearing capacity of the soil base deficiency is solved.

\section{Conclusion}

The developed technology of reinforcement of soil-cement pile reinforcement with the help of drilled-injection piles made by electric discharge technology (EDT) allows solving the problems of strengthening overloaded bases, as well as the arrangement piles with increased load-bearing capacity.

\section{References}

1. V.A. Ilyichev, R.A. Mangushev, N.S. Nikiforova. Experience in the development of the underground space of Russian megacities, Bases, foundations and soil mechanics 2 , 17-20 (2012).

2. V.M. Ulitsky, A.G. Shashkin, K.G. Shashkin. Geotechnical support of urban development. Saint Petersburg: Georekonstrukciya, 551 (2010).

3. D.E. Razvodovsky, A.A. Chepurnova. Evaluation of the effect of strengthening the foundations of buildings on the technology of jet cementation on their sediment, Industrial and civil engineering 10, 64-72 (2016).

4. F. Deckner, K. Viking, S. Hintze. Wave Patterns in the ground: case studies related to vibratory sheet pile driving, Geotechnical and Geological Engineering 35 Iss. 6, 2863-2878 (2017). DOI: 10.1016/j. soildyn.2017.01.039.

5. M. Korff, P. Meijers, A. Wiersma, F. Kloosterman. Mapping liquefaction based on CPT data for induced seismicity in Groningen, Proceedings of the $7^{\text {th }}$ International Conference on Earthquake Geotechnical Engineering. Rome, 3418-3425 (2019).

6. F. Deckner, K. Viking, C. Guillemet, S. Hintze. Instrumentation system for ground vibration analysis during sheet pile driving, Geotechnical Testing Journal 38 Iss. 6 , 893-905 (2015). DOI: 10.1520/GTJ20140275.

7. R.B.J. Brinkgerve. Plaxis: Finite Element Code for Soil and Rock Analyses. Balkema, 53-56 (2006). 
8. N. Denies, A. Holeyman. Shear strength degradation of vibrated dry sand, Soil Dynamics and Earthquake Engineering 95, 106-117 (2017). DOI: 10.1007/s10706-017-0285-x.

9. H. Karol Reuben. Chemical grouting and soil stabilization, American Society of Civil Engineers, 536 (2003).

10. M.P. Moseley. Ground improvement. London, 440 (2004).

11. N.S. Sokolov, S.N. Sokolov, A.N. Sokolov. Fine-grained concrete, as a structural construction material for flight augering piles-EDT, Building material 5, 16-20 (2017).

12. N.S. Sokolov, S.S. Viktorova, G.M. Smirnova, I.P. Fedoseeva. Flight augering piles-EDT as a buried reinforced concrete structure, Building material 9, 47-50 (2017).

13. N.S. Sokolov, S.S. Viktorova. Research and development of a discharge device for the production of a flight augering pile, Bulletin of Chuvash University 3, 152-159 (2017). 